\title{
Cytotoxicity and Reactive Oxygen Species Generated by Ferrocenium and Ferrocene on MCF7 and MCF10A Cell Lines
}

\author{
Claudia Y Acevedo-Morantes ${ }^{1}$, Enrique Meléndez ${ }^{2}$, Surinder P Singh ${ }^{1}$ and Jaime E Ramírez-Vick ${ }^{1 *}$ \\ ${ }^{1}$ Engineering Science \& Materials Department, University of Puerto Rico, P.O. Box 9000, Mayaguez, PR 00681, USA \\ ${ }^{2}$ Department of Chemistry, University of Puerto Rico, P.O. Box 9000, Mayaguez, PR 00681, USA
}

\begin{abstract}
The aim of this study was to investigate the effect of ferrocene $\left(\mathrm{FeCp}_{2}\right)$ and ferrocenium salt $\left(\mathrm{FeCp}_{2} \mathrm{BF}_{4}\right)$ on the viability of MCF7 breast cancer and MCF10A non-tumorigenic epithelial cells and the role of Reactive Oxygen Species (ROS) production in cell cytotoxicity. $\mathrm{FeCp}_{2} \mathrm{BF}_{4}$ displayed higher cytotoxicity than FeCp $\mathrm{p}_{2}$, and the cell type contributes toward complexes toxicity, as MCF7 cells displays greater toxicity than MCF10A cells. The mechanism of toxicity seems to involve the generation of ROS, with MCF7 cells producing higher levels than epithelial cells. In addition, the inhibition of ROS was found to be protective against ferrocene induced cell death. The findings of cancerous cell-induced cytotoxicity by ROS indicate a potential utility of ferrocenyl derivatives in the treatment of cancer.
\end{abstract}

Keywords: Ferrocene; Ferrocenium; Reactive oxygen species; MCF7 cells; MCF10A cells

\section{Introduction}

The accidental discovery of bis(cyclopentadienyl) iron (II) (ferrocene) in 1951 has played an important role in the development of organometallic chemistry $[1,2]$. Ferrocene $\left(\mathrm{FeCp}_{2}\right)$ has been well studied due to its properties and applications in research areas ranging from organic synthesis, catalysis and material science [3-6] (Figure 1). The redox properties as well as its thermodynamic and kinetic stabilities have made ferrocene one of the most widely studied organometallic complexes. The neutral, uncharged complex can undergo one-electron oxidation producing ferrocenium cation. Ferrocenium $\left(\mathrm{FeCp}_{2} \mathrm{BF}_{4}\right)$ has an unpaired electron in one of the non-bonding orbitals $\left(\mathrm{e}_{2 \mathrm{~g}}\right)$ and as a result it is a free radical species of high stability. With these chemical properties, it is not surprising that the $\mathrm{FeCp}_{2} / \mathrm{FeCp}_{2} \mathrm{BF}_{4}$ system has found fertile grounds in the biomedical field.

In 1984 Köpf-Maier and co-workers [7] reported the anticancer properties of $\mathrm{FeCp}_{2} \mathrm{BF}_{4}$ salts in an Ehrlich ascite tumor. Ferrocenium (induce DNA oxidative damage and 8-oxoguanine as a initial product of guanine oxidation $[8,9]$. However, if $\mathrm{FeCp}_{2}$ is transported into the tumor cells, once uptaken, it generates $\mathrm{H}_{2} \mathrm{O}_{2}$ by autooxidation, forming $\mathrm{Fc}^{+}$[10]. To improve $\mathrm{FeCp}_{2}$ uptake by cells, these ferrocenyls have been functionalized with nucleic acids, proteins, hormones, selective endocrine modulators and carbohydrates [11-13].

In the past years, our group has initiated a project investigating the antitumor properties of modified ferrocene (ferrocenyls), in particular modifying the structure with pendant groups on the $\mathrm{Cp}$ ring to make more active and selective anticancer agents. But, there are mechanistic

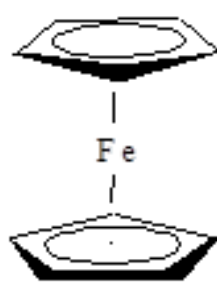

Figure 1: Structure of ferrocene. details on $\mathrm{FeCp}$ that need to be investigated in more depth. In this regard, the mechanistic studies reported independently by Osella and Kovjazin et al. $[9,10]$ might be contradictory. For instance, Osella and collaborators [9] demonstrated that the cytotoxic effect of ferrocenium is associated to the production hydroxyl radicals under physiological conditions and nuclear DNA, cell membrane and topoisomerase II are the possible targets, whereas ferrocene has no inhibitory effect on cancer cells $[8,9]$. In contrast, Kovjazin and collaborators [10] reported that ferrocene can produce free radical species and its antitumor activity is mediated by immune stimulation. Thus, we decided to investigate the ROS production of ferrocenium versus the non toxic $\mathrm{FeCp}_{2}$ and correlate it with their cytotoxicity in the MCF7 breast cancer cell line. Herein we report our findings.

\section{Materials and Methods}

\section{Cell culture}

Human breast adenocarcinoma MCF7 cells (ATCC, Cat. HTB-22) were all adapted and maintained in MEME supplemented with $2 \mathrm{mM}$ L-glutamine, $1 \mathrm{mM}$ sodium pyruvate, $0.01 \mathrm{mg} / \mathrm{ml}$ bovine insulin, $10 \%$ fetal bovine serum (FBS) (all reagents from Sigma-Aldrich) and 100 units/ml penicillin $\mathrm{G} / 100 \mu \mathrm{g} / \mathrm{ml}$ streptomycin sulfate (Lonza, Cat. 17603E). Human mammary epithelial MCF10A cells (ATCC, Cat. CRL10317) were maintained in MEBM (MEGM bullet kit, Lonza, Cat. CC3150) supplemented with $13 \mathrm{mg} / \mathrm{ml} \mathrm{BPE,} 0.5 \mathrm{mg} / \mathrm{ml}$ hydrocortisone, $10 \mu \mathrm{g} / \mathrm{ml} \mathrm{hEGF}, 5 \mathrm{mg} / \mathrm{ml}$ bovine insulin, $100 \mathrm{ng} / \mathrm{ml}$ cholera toxin and 100 units $/ \mathrm{ml}$ penicillin $\mathrm{G} / 100 \mu \mathrm{g} / \mathrm{ml}$ streptomycin sulfate (Lonza, Cat. 17-603E). Cell cultures were incubated in a humidified $5 \% \mathrm{CO}_{2}$

*Corresponding author: Jaime E. Ramírez-Vick, Engineering Science \& Materials Department, University of Puerto Rico, P.O. Box 9000, Mayaguez, PR 00681, USA E-mail: jaimee.ramirez@upr.edu

Received July 02, 2012; Accepted August 16, 2012; Published August 18, 2012 Citation: Acevedo-Morantes CY, Meléndez E, Singh SP, Ramírez-Vick JE (2012) Cytotoxicity and Reactive Oxygen Species Generated by Ferrocenium and Ferrocene on MCF7 and MCF10A Cell Lines. J Cancer Sci Ther 4: 271-275. doi:10.4172/1948-5956.1000154

Copyright: (C) 2012 Acevedo-Morantes CY, et al. This is an open-access article distributed under the terms of the Creative Commons Attribution License, which permits unrestricted use, distribution, and reproduction in any medium, provided the original author and source are credited. 
Citation: Acevedo-Morantes CY, Meléndez E, Singh SP, Ramírez-Vick JE (2012) Cytotoxicity and Reactive Oxygen Species Generated by Ferrocenium and Ferrocene on MCF7 and MCF10A Cell Lines. J Cancer Sci Ther 4: 271-275. doi:10.4172/1948-5956.1000154

atmosphere at $37^{\circ} \mathrm{C}$. Strict attention was paid to using cells when in the logarithmic phase of cell growth. Cells were seeded in 96-well plates at a final concentration of $5 \times 10^{4}$ cells $/ \mathrm{ml}$.

\section{Cell viability}

Cell viability was assessed using the cell permeant and nonfluorescent probe calcein AM (Anaspec, Cat. 89201). Cells were seeded in 96-well plates at a concentration of $5 \times 10^{4} \mathrm{cells} / \mathrm{ml}$ and incubated overnight. Cells were then washed with Phosphate Buffered Saline solution (PBS) and incubated with $4 \mu \mathrm{M}$ calcein $\mathrm{AM}$, during $40 \mathrm{~min}$ at $37^{\circ} \mathrm{C}$ and washed again with $\mathrm{PBS}$. Antibiotic-free medium containing various concentrations of the ferrocene complexes in $5 \%$ DMSO/95\% medium were added to the wells. The concentrations used for $\mathrm{FeCp}_{2}$ were 25, 50, 100, 250, 500, 1000, 1500, 2000, 2500 and $3000 \mu \mathrm{M}$ and for $\mathrm{FeCp}_{2} \mathrm{BF}_{4}$ 2.5, 5, 10, 25, 50, 100, 150, 200, 250 and $300 \mu \mathrm{M}$. Three independent measurements were carried out for every concentration. After 1, 2, 3, 4, 12, 24 and $48 \mathrm{~h}$ of $\mathrm{FeCp}_{2}$ or $\mathrm{FeCp}_{2} \mathrm{BF}_{4}$ exposure, the fluorescence was measured at $530 \mathrm{~nm}$. Three controls were set up for each experiment: 1) IC $_{0}$ consisting of cells without the ferrocene complexes (representing $100 \%$ growth), 2) $\mathrm{IC}_{100}$ consisting of medium alone (representing $0 \%$ growth) and 3) cells growing on $5 \%$ $\mathrm{DMSO} / 95 \%$ medium (to determine the cytotoxic effect of DMSO in the medium). Background fluorescence, due to the non-specific binding was subtracted from the measurements of exposed cells. For $\mathrm{IC}_{50}(50 \%$ inhibitory concentration) calculations, survival data were analyzed by dose-response curve fitting using Prism 4.0 (GraphPad, San Diego, CA). Fluorescence was measured using a Perkin Elmer HTS 7000 (MA, USA) microplate reader.

\section{Measurement of reactive oxygen species (ROS)}

To assess ROS production, MCF7 and MCF10A cells were treated with the oxidation-sensitive dye, 2',7'-dichlorodihydrofluorescein diacetate ( $\mathrm{H}_{2} \mathrm{DCF}-\mathrm{DA}$, Invitrogen, Cat. D399). The oxidation product of $\mathrm{H}_{2}$ DCF-DA generates the fluorescent 2',7'-dichlorofluorescein (DCF) which has excitation/emission maxima of $\sim 495 / 529 \mathrm{~nm}$. Cells were seeded in 96-well plates at a concentration of $5 \times 10^{4} \mathrm{cells} / \mathrm{ml}$ and cultured with different concentrations of $\mathrm{FeCp}_{2}$ or $\mathrm{FeCp}_{2} \mathrm{BF}_{4}$ (as described above). After 1, 2, 3, 4, 12, 24 and $48 \mathrm{~h}$ of treatment, cultures were loaded with $10 \mu \mathrm{M}$ of $\mathrm{H}_{2}$ DCF-DA and incubated for 40 minutes at $37^{\circ} \mathrm{C}$, after which time ROS production was evaluated at $530 \mathrm{~nm}$, with $\mathrm{H}_{2} \mathrm{O}_{2}$ as positive control.

\section{ROS quenching}

To determine ROS production in $\mathrm{FeCp}_{2}-$ or $\mathrm{FeCp}_{2} \mathrm{BF}_{4}$-induced cell death, MCF7 and MCF10A cells were seeded in 96-well plates at a concentration of $5 \times 10^{4}$ cells $/ \mathrm{ml}$. N-acetyl cysteine (NAC, SigmaAldrich Cat. A9165) was added to the cells at $10 \mathrm{mM}$ for $1 \mathrm{~h}$. After $\mathrm{NAC}$ pretreatment, cells were cultured with $\mathrm{FeCp}_{2}$ or $\mathrm{FeCp}_{2} \mathrm{BF}_{4}$ (at the concentrations described above). ROS production was determined by adding $\mathrm{H}_{2}$ DCFDA to pretreated cell cultures and recording the DCF fluorescence at $530 \mathrm{~nm}$.

\section{Statistical analysis}

All data was analyzed using GraphPad Prism 4 software (GraphPad Software, Inc., San Diego, CA). Data for the viability assay was transformed, normalized and statistically analyzed using a dose-response curve fitting with significance levels defined as $p<0.05$. Statistical analysis for the ROS production data was performed using a two-way ANOVA.

\section{Results Morphological evaluation of MCF7 and MCF10A Cells by
microscopy}

The morphological changes on MCF7 cells were visualized by inverted microscopy, after exposing the cells to different concentrations of ferrocenes (as described previously). The MCF7 cells without treatment (used as control) show a uniform distribution maintaining an integral cellular membrane. Given the fact that $\mathrm{FeCp}_{2}$ is not toxic at low concentrations and ferrocenium cytotoxicity is low, we used high concentrations for the study to detect the ROS and morphological changes. After $12 \mathrm{~h}$ of exposure, MCF7 cells treated with up to 500 $\mu \mathrm{M} \mathrm{FeCp}$, showed no significant difference when compared with controls (data not shown). However, at concentrations of $1000 \mu \mathrm{M}$ $\mathrm{FeCp}_{2}$ or higher, MCF7 cells were detached and morphologically rounded, different when compared with the controls. Similar morphological changes were observed in MCF10A cells (data not shown). Morphological evaluation by microscopy was also performed for MCF7 and MCF10A cells at longer drug exposure times. At $24 \mathrm{~h}$ exposure, with 1000, 1500, 2000 and $3000 \mu \mathrm{M}$ of $\mathrm{FeCp}_{2}$, MCF7 cells exhibited morphological changes characteristic of apoptosis, including karyopycnosis, oversized cytoplasmic particles, damaged organelles and rupture of the cytoplasmic membrane and nuclear envelope. Figure 2A shows the morphological changes in MCF7 cells after exposure to maximum concentration of $\mathrm{FeCp}_{2}$ during $24 \mathrm{~h}$. More significant morphological changes were observed after $48 \mathrm{~h}$ of exposure time. For MCF10A cells, similar morphological changes to those of MCF7 were obtained at 24 and $48 \mathrm{~h}$ (data not shown).

Morphological changes induced by $\mathrm{FeCp}_{2} \mathrm{BF}_{4}$ on MCF7 and MCF10A cells were also examined. After $12 \mathrm{~h}$ of exposure, MCF7 and MCF10A cells to $\mathrm{FeCp}_{2} \mathrm{BF}_{4}$ at a concentration below $50 \mu \mathrm{M}$, these showed no significant difference when compared with controls. However, at concentration between 100 and $300 \mu \mathrm{M}$ of $\mathrm{FeCp}_{2} \mathrm{BF}_{4}$, MCF7 cells were detached and morphologically rounded. Similar morphological changes were seen with MCF10A cells upon exposure to

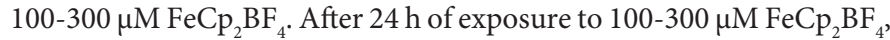
MCF7 cells exhibited almost identical morphological changes as those observed when exposed to $\mathrm{FeCp}_{2}$ but at concentrations an order of magnitude higher These include apoptosis with karyopycnosis, oversized cytoplasmic particles, damaged organelles and ruptured cytoplasmic membrane and nuclear envelope. Figure 2B shows the morphological changes in MCF7 cells after a $24 \mathrm{~h}$ exposure to 300 $\mu \mathrm{M} \mathrm{FeCp} \mathrm{BF}_{4}$. These results indicate that ferrocenium is more active than $\mathrm{FeCp}_{2}$ in inducing cell damage. At $50 \mu \mathrm{M}$ there was a reduction in the number of the cells and the remaining cells seemed attached but
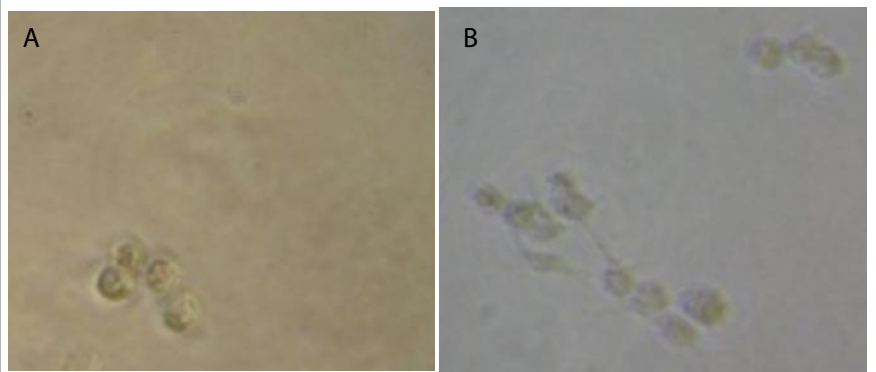

Figure 2: MCF-7 cells exposure to (A) FeCp $3000 \mu \mathrm{M}$ or (B) FeCp $\mathrm{BF}_{4} 300$ $\mu \mathrm{M}$ during $24 \mathrm{~h}$. Cells were visualized by inverted microscope. Magnification, 10X, insets, $40 \mathrm{X}$. 
Citation: Acevedo-Morantes CY, Meléndez E, Singh SP, Ramírez-Vick JE (2012) Cytotoxicity and Reactive Oxygen Species Generated by Ferrocenium and Ferrocene on MCF7 and MCF10A Cell Lines. J Cancer Sci Ther 4: 271-275. doi:10.4172/1948-5956.1000154

morphologically different (rounded) when compared with controls. A similar effect was observed on MCF10A cells (data not shown).

\section{Cell viability studies}

To determine if $\mathrm{FeCp}_{2}$ and $\mathrm{FeCp}_{2} \mathrm{BF}_{4}$ toxicity was dependent upon the cellular microenvironment, the cytotoxic activity of these compounds was measured on MCF7 cells and compared to MCF10A cells. Both types of cells were treated with $25-3000 \mu \mathrm{M} \mathrm{FeCp} \mathrm{p}_{2}$ or with 2.5-300 $\mu \mathrm{M} \mathrm{FeCp}{ }_{2} \mathrm{BF}_{4}$, at time intervals of $1,2,3,4,12,24$ and $48 \mathrm{~h}$. Figure 3 shows the viability of MCF7 cells upon exposure to $\mathrm{FeCp}$ and $\mathrm{FeCp}_{2} \mathrm{BF}_{4}$ as function of time. Curve fitting of the survival data of the cell lines in response to various concentrations of the agents was used to calculate $\mathrm{IC}_{50}$ values. For MCF7 cells, $\mathrm{FeCp}$, displayed an $\mathrm{IC}_{50}$ of $1421 \pm 5.3 \mu \mathrm{M}$ (Figure $3 \mathrm{~A}$ ) and 261.98 \pm 1.5 (Figure 4B) were determined at $24 \mathrm{~h}$. These results are in agreement with previous published data [11], which show a significant dose-dependent antiproliferative effect of these complexes. These $\mathrm{IC}_{50}$ values correspond very well with the concentrations of the complexes that induced significant morphological changes. Evaluation of the MCF7 and MCF10A cells showed that after $12 \mathrm{~h}$ at concentrations above $1000 \mu \mathrm{M}$ for $\mathrm{FeCp}_{2}$ or above $100 \mu \mathrm{M}$ for $\mathrm{FeCp}_{2} \mathrm{BF}_{4}$, these compounds induced morphological changes in cells, with $\mathrm{FeCp}_{2} \mathrm{BF}_{4}$ showing a higher cytotoxicity than FeCp For MCF7 cells it can be seen that at log values of about 3.000 and 0.699 for $\mathrm{FeCp}_{2}$ and $\mathrm{FeCp}_{2} \mathrm{BF}_{4}$, respectively, there is a marked drop in cell viability which increases with time. At higher concentrations the drop in cell viability is less pronounced and is less dependent on time. In the case of MCF10A this effect is more subtle and the drop in cell viability decrease steadily with concentration. The stronger effect on

A

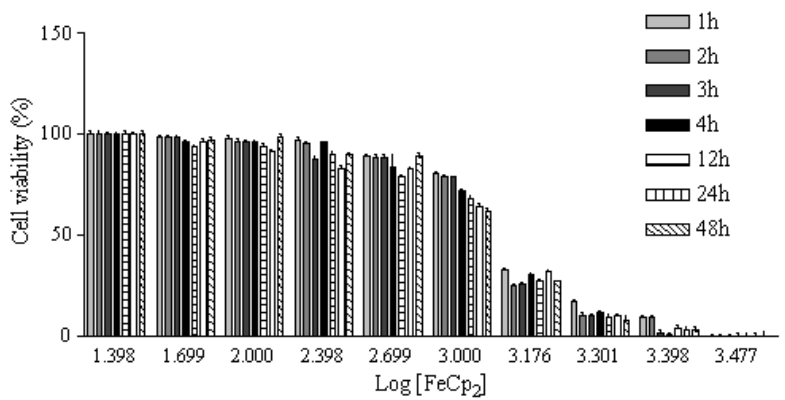

B

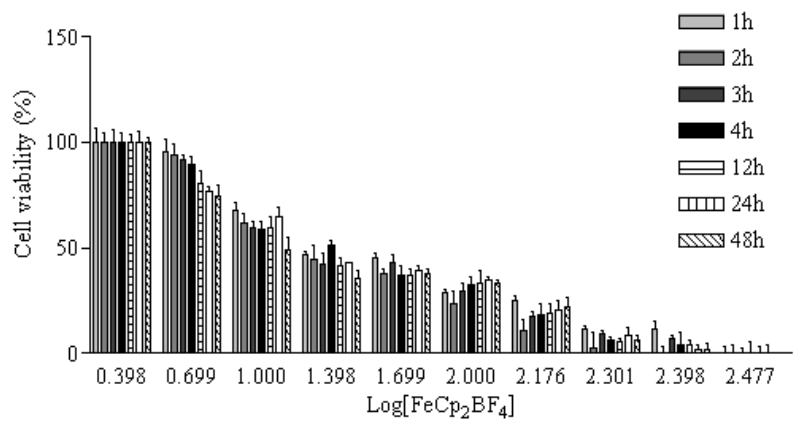

Figure 3: Effect of $\mathrm{FeCp}$ and $\mathrm{FeCp}_{2} \mathrm{BF}_{4}$ on MCF7 cells viability determined by calcein accumulation. MCF7 cells were exposed to (A) $\mathrm{FeCp}_{2}$ and (B) FeCp $\mathrm{BF}_{4}$, at different concentrations during 1, 2, 3, 4, 12, 24 and $48 \mathrm{~h}$. Each point represents mean value $+S D$, with a number of replicates, $n=3(p<$ 0.05).
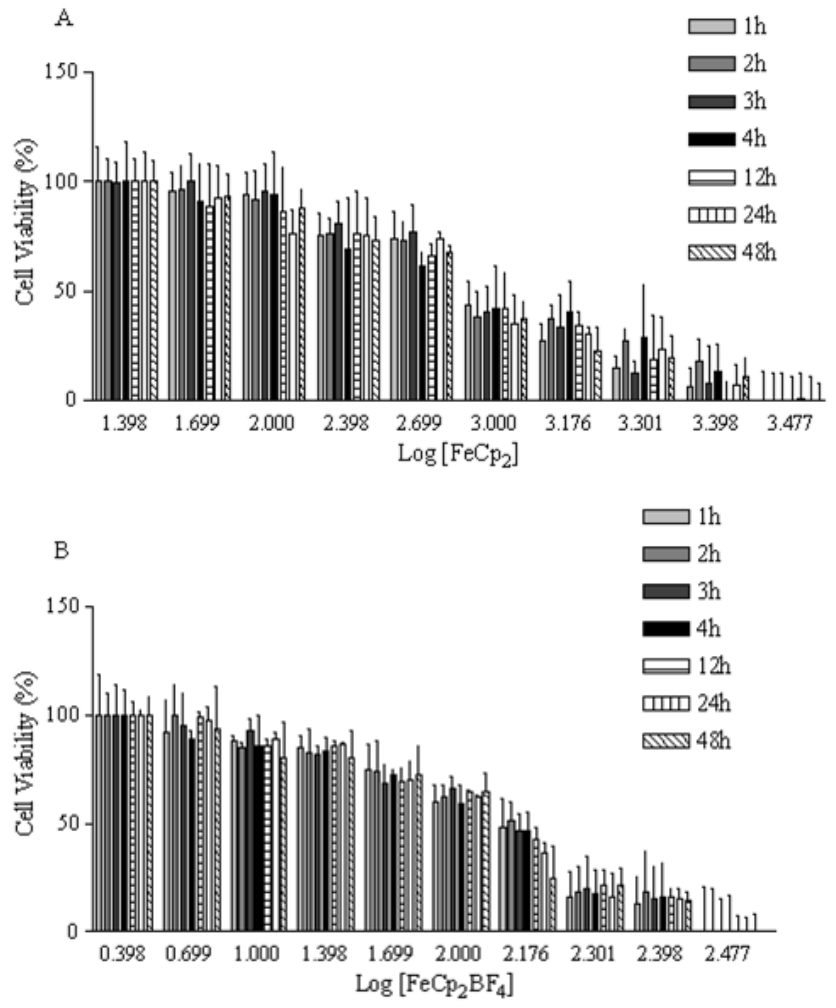

Figure 4: Effect of $\mathrm{FeCp}$ and $\mathrm{FeCp}_{2} \mathrm{BF}_{4}$ on MCF10A cells viability determined by calcein accumulation.MCF10A cells were exposed to (A) $\mathrm{FeCp}$, and (B) $\mathrm{FeCp}_{2} \mathrm{BF}_{4}$, at different concentrations during 1, 2, 3, 4, 12, 24 and $48 \mathrm{~h}$. Each point represents mean value $\pm S D$, with a number of replicates, $n=3(p<$ $0.05)$.

cell viability of $\mathrm{FeCp}_{2} \mathrm{BF}_{4}$ over $\mathrm{FeCp}$, seen with MCF7 can also be seen in MCF10A cell, with similar $\mathrm{IC}_{50}$ values for both cell lines. $1.5 \mu \mathrm{M}$ for $\mathrm{FeCp}_{2} \mathrm{BF}_{4}$ (Figure 3B), whereas for MCF10A cells an $\mathrm{IC}_{50}$ of $1250 \pm 8.3$ $\mu \mathrm{M}$ for $\mathrm{FeCp}_{2}$ (Figure $4 \mathrm{~A}$ ) and $126 \pm 13.79 \mu \mathrm{M}$ for $\mathrm{FeCp}_{2} \mathrm{BF}_{4}$

\section{Measurement of ROS production induced-ferrocenes in MCF7 and MCF10A cells}

Experiments were performed to determine whether the MCF7 and MCF10A cytotoxicity from $\mathrm{FeCp}$ or $\mathrm{FeCp}_{2} \mathrm{BF}_{4}$ exposure could be related to the generation of intracellular ROS. Cellular production of ROS was measured at 1, 2, 3, 4, 12, 24 and $48 \mathrm{~h}$ after $\mathrm{FeCp}_{2}$ or $\mathrm{FeCp}_{2} \mathrm{BF}_{4}$ exposure, using the $\mathrm{H}_{2}$ DCF-DA dye. There was a significant $(\mathrm{p}<0.05)$ increase in ROS in MCF7 cells at FeCp $\mathrm{p}_{2}$ concentrations above $1000 \mu \mathrm{M}$, as shown in Figure 5A (Supplementary Figure S1). This concentration is a threshold before which exposure time played a significant role in ROS production. In addition, this threshold concentration correlates with the point at which there was a significant drop in cell viability. Results for MCF10A cells show a similar threshold concentration at which there is a significant increase in ROS and that this correlates with a drop in cell viability, although at lower levels than for MCF7 cells (Figure 6A). Higher levels of ROS were detected when exposing MCF7 and MCF10A cells to $\mathrm{FeCp}_{2} \mathrm{BF}_{4}$ (Figures $5 \mathrm{~B}$ and 6B; and Supplementary Figure S2), although two fold lower levels were detected for the latter. Previous studies have reported that the antitumor properties shown by exposure to $\mathrm{FeCp}_{2}$ could be due to the metabolic formation of ferrocenium ions $\left(\mathrm{Cp}_{2} \mathrm{Fe}^{+}\right)$, which in turn induce oxidative damage 
Citation: Acevedo-Morantes CY, Meléndez E, Singh SP, Ramírez-Vick JE (2012) Cytotoxicity and Reactive Oxygen Species Generated by Ferrocenium and Ferrocene on MCF7 and MCF10A Cell Lines. J Cancer Sci Ther 4: 271-275. doi:10.4172/1948-5956.1000154

to DNA [12,13]. A possible mechanism for the action of ferrocenyl derivatives have been proposed in $\mathrm{T}$ lymphocytes, in which, $\mathrm{p} 21^{\mathrm{ras}}$ activates $\mathrm{T}$-cells through an oxidative stress-mediated mechanism that elicits an immune stimulatory effect [10].

\section{Role of $\mathrm{ROS}$ in $\mathrm{FeCp}_{2}$ or $\mathrm{FeCp}_{2} \mathrm{BF}_{4}$ induced cytotoxicity}

To provide further evidence that ROS production is in fact being generated due to $\mathrm{FeCp}_{2}$ or $\mathrm{FeCp}_{2} \mathrm{BF}_{4}$ exposure, the antioxidant $\mathrm{NAC}$ was added prior to treatment with $\mathrm{FeCp}_{2}$ or $\mathrm{FeCp}_{2} \mathrm{BF}_{4}$ to quench ROS. Supplementary Figures S1A and S1B, shows that NAC has significant effect in preventing ROS induced by $\mathrm{FeCp}_{2}$ or $\mathrm{FeCp}_{2} \mathrm{BF}_{4}$ on $\mathrm{MCF} 7$ and on MCF10A cells (Supplementary Figure S3 and S4). In this study significant differences were observed between treated with $10 \mathrm{mM}$ $\mathrm{NAC}$, for each concentration tested of $\mathrm{FeCp}_{2}$ and $\mathrm{FeCp}_{2} \mathrm{BF}_{4}$. These results are in agreement with previous studies showing the crucial role of ROS in nanoparticle (NP)-induced cytotoxicity, in which cells exposed to $10 \mathrm{mM}$ NAC cells remain viable even at NP concentration previously shown to reduce cell viability below $10 \%$ [14].

\section{Discussion}

In this study we correlate the cytotoxic effect of $\mathrm{FeCp}_{2}$ and $\mathrm{FeCp}_{2} \mathrm{BF}_{4}$ on MCF7 breast cancer cells and MCF10A mammary epithelial cells with the ROS production. Here we present novel findings demonstrating that cancerous breast cells are markedly more susceptible (i.e, 2-3 times) to $\mathrm{FeCp}_{2}$ or $\mathrm{FeCp}_{2} \mathrm{BF}_{4}$-mediated toxicity than their normal counterparts. In addition, cell show an order of magnitude lower $\mathrm{IC}_{50}$ values for $\mathrm{FeCp}_{2} \mathrm{BF}_{4}$. The higher cytotoxicity shown by $\mathrm{FeCp}_{2} \mathrm{BF}_{4}$ over $\mathrm{FeCp}_{2}$ could be explained mainly by the former agent being a water-
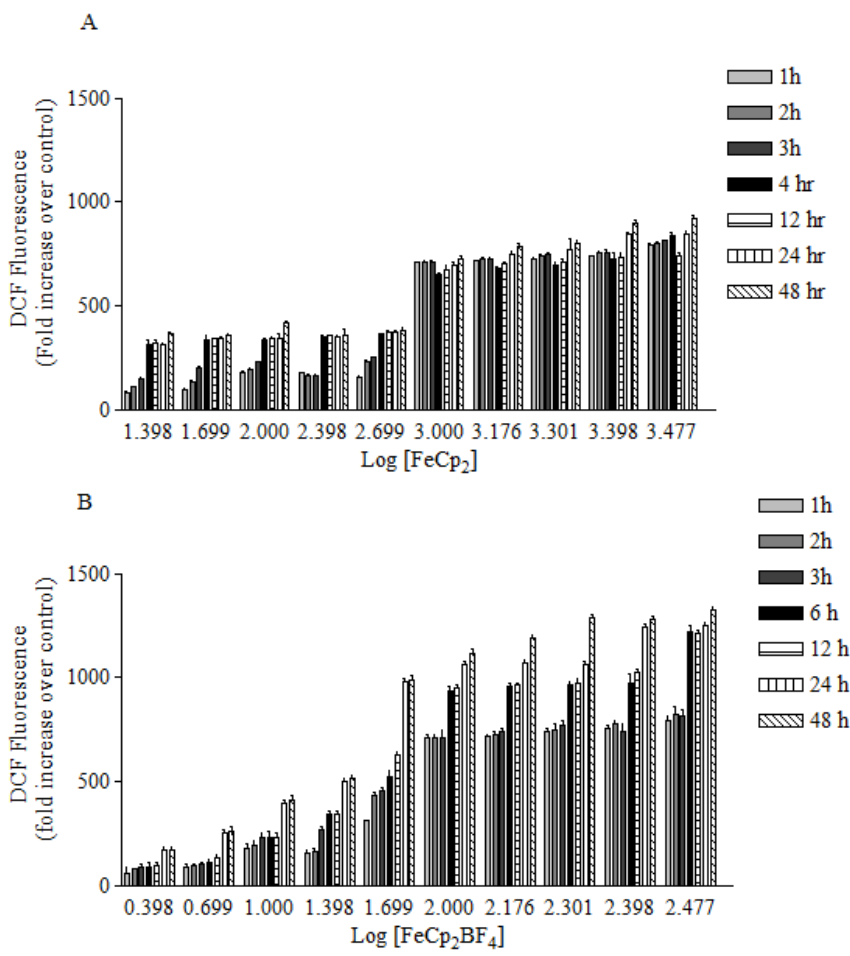

Figure 5: ROS production induced by $(\mathrm{A}) \mathrm{FeCp}_{2}$ or $(\mathrm{B}) \mathrm{FeCp}_{2} \mathrm{BF}$ generated on MCF7 cells at concentrations ranging from 25 to $3000 \mu \mathrm{M}$ or 2.5 to $300 \mu \mathrm{M}$, respectively, and at different time of exposure. Significant increments were observed at concentrations $1000 \mu \mathrm{M} \mathrm{FeCp}$ or higher and $100 \mu \mathrm{M} \mathrm{FeCp}_{2} \mathrm{BF}_{4}$ or higher.

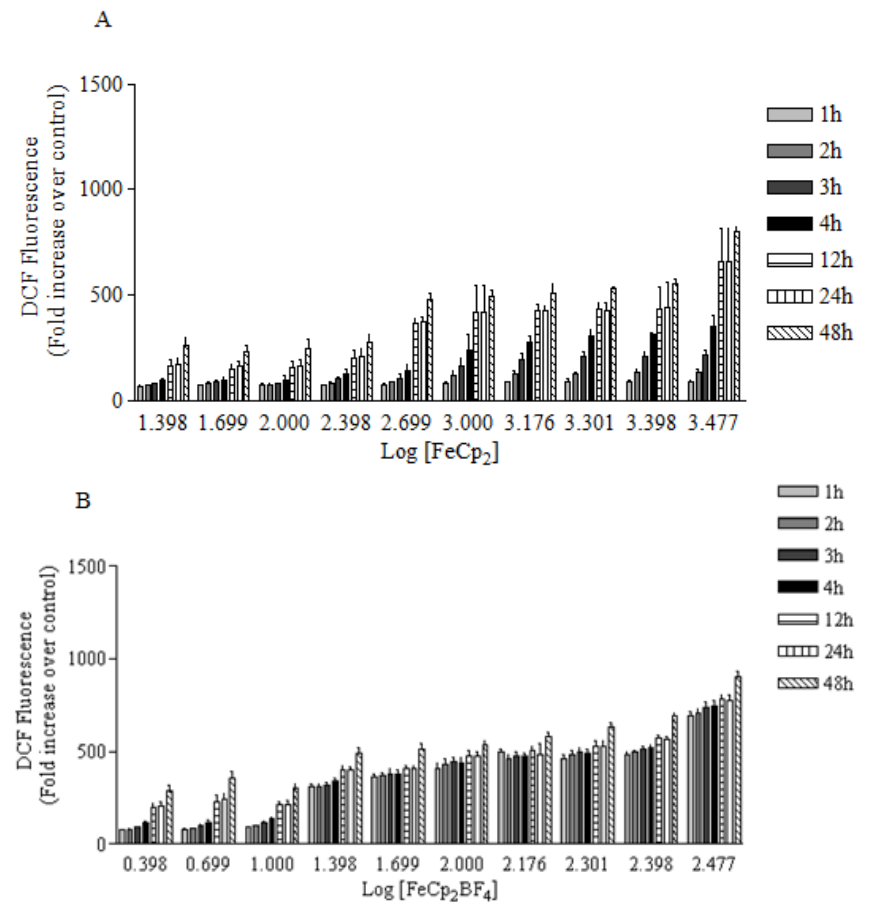

Figure 6: ROS production induced by (A) $\mathrm{FeCp}_{2}$ or (B) $\mathrm{FeCp}_{2} \mathrm{BF}_{4}$ generated on MCF10A cells at concentrations ranging from 25 to $3000 \mu \mathrm{M}$ or 2.5 to $300 \mu \mathrm{M}$, respectively, and at different time of exposure. Significant increments were observed at concentrations $1000 \mu \mathrm{M} \mathrm{FeCp} p_{2}$ or higher and 100 $\mu \mathrm{M} \mathrm{FeCp} \mathrm{BF}_{4}$ or higher.

soluble stable cation, which has better access to the negatively-charged MCF7 and MCF10A surface [15]. These findings may be of important clinical interest as one of the greatest challenges facing chemotherapy is the inability of anticancer drugs to effectively distinguish between normal and cancerous tissues. These findings are in agreement with previous studies, showing that rapidly dividing tumor cells are more susceptible to different activation stimuli resulting in different toxicity responses, when compared to quiescent cells. The preferential killing of the rapidly dividing cancer cells relative to quiescent cells of the same lineage suggest that the mechanisms of these complexes toxicity might be related to the proliferative potential of the cell [14]. Our findings that the cell viability was related to the ROS production, suggest that increasing in ROS levels exceeds the capacity of the cellular antioxidant defense system, and causes cells to enter a state of oxidative stress which results in damage of cellular components such as lipids, protein and DNA [16]. The oxidation of fatty acids then leads to the generation of lipid peroxides that initiate a chain reaction leading to disruption of plasma and organelle membranes and subsequent cell death. The persistent oxidative stress that characterizes cancer cells has been proposed as the basis for a strategy to develop new therapeutic strategies based on ROS-inducing agents [17]. Based on our results, ferrocenes and their derivatives seem as good candidates for this therapeutic strategy. In addition, our findings reveals a concentration and time dependent increase in ROS production in both cell types, with higher levels been observed in MCF7 cancerous cells consistent with the ability of these cells to generate large amounts of ROS. In fact, our studies using the ROS quencher, NAC, demonstrated the causal role of ROS generation in $\mathrm{FeCp}_{2}$ or $\mathrm{FeCp}_{2} \mathrm{BF}_{4}$-mediated cytotoxicity. These findings further support that functionalization of ferrocene with 
Citation: Acevedo-Morantes CY, Meléndez E, Singh SP, Ramírez-Vick JE (2012) Cytotoxicity and Reactive Oxygen Species Generated by Ferrocenium and Ferrocene on MCF7 and MCF10A Cell Lines. J Cancer Sci Ther 4: 271-275. doi:10.4172/1948-5956.1000154

pendant groups that facilitate the entrance of ferrocene inside the cell and modulate the redox chemistry inside the cell is worth pursuing [11-13,18-23]. For instance, a series ferrocenyls functionalized with selective endocrine receptor modulator (ERM) have reported [19]. These ferrocifens elicit their antiproliferative effects mediated by the pendant groups (ERM) which act as a antagonist and a redox antenna [19]. Therefore, lipophilicity, molecular recognition and redox chemistry must be considered when designing ferrocenyl anticancer agent [8-23].

\section{Acknowledgement}

E.M. acknowledges the NIH-MBRS SCORE Programs at the University of Puerto Rico Mayagüez for financial support via NIH-MBRS-SCORE Program grant \#S06 GM008103-37.

\section{References}

1. Kealy TJ, Pauson PJ (1951) A New Type of Organ-Iron Compound. Nature 168: $1039-1040$

2. Miller SA, Tebboth JA, Treamaine JF (1952) Dicyclopentadienyliron. J Am Chem Soc 632-635.

3. Togni A, Hayashi T (1995) Ferrocenes: Homogenoeous catalysis, organic synthesis, material science. VCH, Weinheim, Germany.

4. Gómez Arrayás R, Adrio J, Carretero JC (2006) Recent applications of chira ferrocene ligands in asymmetric catalysis. Angew Chem Int Ed Engl 45: 7674 7715 .

5. Togni A, Halterman RL (1998), Metallocenes. Wiley-VCH, Weinheim, Germany.

6. Atkinson RC, Gibson VC, Long NJ (2004) The syntheses and catalytic applications of unsymmetrical ferrocene ligands. Chem Soc Rev 33: 313-328.

7. Köpf-Maier P, Köpf H, Neuse EW (1984) Ferricenium complexes: a new type of water-soluble antitumor agent. J Cancer Res Clin Oncol 108: 336-340.

8. Tabbi G, Cassino C, Cavigiolio G, Colangelo D, Ghiglia A, et al. (2002) Water stability and cytotoxic activity relationship of a series of ferrocenium derivatives. ESR insights on the radical production during the degradation process. J Med Chem 45: 5786-5796.

9. Osella D, Mahboobi H, Colangelo D, Cavigiolio G, Vessieres A, et al. (2005) FACS analysis of oxidative stress induced on tumor cells by SERMs. Inorg Chim Acta 358: 1993-1998.

10. Kovjazin R, Eldar T, Patya M, Vanichkin A, Lander HM, et al. (2003) Ferrocene- induced lymphocyte activation and anti-tumor activity is mediated by redoxsensitive signaling. FASEB J 17: 467-469.

11. Top S, Vessières A, Leclercq G, Quivy J, Tang J, et al. (2003) Synthesis, Biochemical Properties and molecular modelling studies of organometallic specific estrogen receptor modulators (SERMs), the ferrocifens and hydroxyferrocifens: evidence for an antiproliferative effect of hydroxyferrocifens on both hormone-dependent and hormone-independent breast cancer cell lines. Chemistry 9: 5223-5236.

12. Ming-Gao L, Hernández R, Matta J, Meléndez E (2009) Synthesis, structure, electrochemistry and cytotoxic properties of ferrocenyl ester derivatives. Met Based Drugs 2009: 420784.

13. Wang T, Wan P, Ma L (2006) Synthesis and Characterization of Alkoxy and Phenoxy-substituted Ferrocenium Salt Cationic Photoinitiators. Chinese J Chem Eng 14: 806-809.

14. Hanley C, Layne J, Punnoose A, Reddy KM, Coombs I, et al. (2008) Preferentia killing of cancer cells and activated human $\mathrm{T}$ cell using $\mathrm{ZnO}$ nanoparticles. Nanotechnology 19: 295103.

15. Zhang Y, Yang M, Park JH, Singelyn J, Ma H, et al. (2009) A surface-charge study on cellular-uptake behavior of F3-peptide-conjugated iron oxide nanoparticles. Small 5: 1990-1996.

16. Lovrić J, Cho SJ, Winnik FM, Maysinger D (2005) Unmodified cadmium telluride quantum dots induce reactive oxygen species formation leading to multiple organelle damage and cell death. Chem Biol 12: 1227-1234.

17. Trachootham D, Alexandre J, Huang P (2009) Targeting cancer cells by ROSmediated mechanisms: a radical therapeutic approach? Nat Rev Drug Discov 8: 579-591.

18. Jaouen G (2006) Bioorganometallics. Wiley-VCH, Weinheim, Germany.

19. Hillard EA, Vessières A, Jaouen G (2010) Ferrocene Functionalized Modulators as Anticancer Agents. Top Organomet Chem 32: 81-117.

20. van Staveren DR, Metzler-Nolte N (2004) Bioorganometallic chemistry of ferrocene. Chem Rev 104: 5931-5985.

21. Fouda MFR, Abd-Elzaher MM, Abdelsamaia RA, Labib AA (2007) On the medicinal chemistry of ferrocene. App Organometal Chem 21: 613-625.

22. Gasser G, Ott I, Metzler-Nolte N (2011) Organometallic Anticancer Compounds J Med Chem 54: 3-25.

23. Vera J, Gao LM, Santana A, Matta J, Meléndez E (2011) Vectorized ferrocenes with estrogens and vitamin D2: synthesis, cytotoxic activity and docking studies. Dalton Trans 40: 9557-9565. 